\title{
KANDUNGAN LOGAM BERAT ARSEN PADA ALGA Kappaphycus alvarezii SERTA SEDIMEN DI PERAIRAN DESA BUKU KECAMATAN BELANG KABUPATEN MINAHASA TENGGARA
}

\author{
(ARSENIC HEAVY METAL CONTENT IN Kappaphycus alvarezii ALGAE AND SEDIMENTS IN \\ THE WATERS OF BUKU VILLAGE, BELANG DISTRICT, MINAHASA TENGGARA)
}

\section{Laurenzy Tampongangoy ${ }^{1}$, Desy M. H. Mantiri ${ }^{{ }^{\star}}$, Darus S. J. Paransa ${ }^{1}$, Rizald M. Rompas ${ }^{1}$, James J. H. Paulus, Suzanne L. Undap ${ }^{2}$}

1. Program Studi IImu Kelautan, Fakultas Perikanan dan IImu Kelautan, UNSRAT.

2. Program Studi Budidaya Perairan, Fakultas Perikanan dan IImu Kelautan, UNSRAT. Corresponding author:dmh_mantiri@unsrat.ac.id

\begin{abstract}
Kappaphycus alvarezii is one species algae that is very widely developed in the tropical waters, especially in Indonesia. The potential in these waters may decrease due to heavy metal pollution that accumulates in algae and sediments. Analyzing the content of heavy metal arsenic (As), using the SNI 01-2896-1998 test method, namely the metal contamination test method in food. The results obtained from this study were samples of brown and green Kapapphycus alvarezii taken from week I-V detected containing heavy metal arsenic (As) ranging from $0.17-0.42 \mathrm{ppm}$ for green algae and $0.12-0.37 \mathrm{ppm}$ for brown algae. This As concentration does not exceed the maximum heavy metal limit, which is $1.0 \mathrm{ppm}$ for the maximum limit for heavy metal contamination in food. The concentration of heavy metal in sediments is $1.12 \mathrm{ppm}$, not exceeding the quality standard in the Environmental Protection Agency (EPA), the maximum heavy metal limit for arsenic in sediment is below $10 \mathrm{mg} / \mathrm{kg}$.
\end{abstract}

Keywords: Kapapphycus alvarezii, arsenic metal, sediment, Buku village waters

\begin{abstract}
Abstrak
Alga Kappaphycus alvarezii merupakan salah satu jenis alga yang sangat banyak dikembangkan di daerah tropis khususnya di Indonesia. Potensi di perairan ini dapat saja mengalami penurunan yang diakibatkan oleh pencemaran logam berat yang terakumulasi pada alga dan sedimen. Menganalisis kandungan logam berat arsen (As), menggunakan metode uji SNI 01-2896-1998 yaitu metode uji cemaran logam dalam makanan. Hasil yang diperoleh dari penelitian ini yaitu sampel alga Kapapphycus alvarezii warna coklat dan hijau yang diambil dari minggu I-V terdeteksi mengandung logam berat arsen (As) berkisar $0.17-0.42 \mathrm{ppm}$ untuk alga hijau dan $0.12-0.37 \mathrm{ppm}$ untuk alga coklat. Konsentrasi As ini tidak melebihi batas maksimum logam berat yaitu $1.0 \mathrm{ppm}$ untuk batas maksimum cemaran logam berat dalam pangan. Untuk kandungan logam berat pada sedimen konsentrasinya sebesar $1.12 \mathrm{ppm}$, tidak melebihi standar baku mutu pada Environmental Protection Agency (EPA) batas logam berat arsen pada sedimen maksimum $<10 \mathrm{mg} / \mathrm{kg}$.
\end{abstract}

Kata kunci: Kappaphycus alvarezii, logam arsen, sedimen, Perairan Desa Buku 


\section{PENDAHULUAN}

Indonesia dikenal sebagai negara kepulauan terbesar di dunia, dengan potensi sumber daya laut dan pesisir yang sangat menjanjikan baik potensi perikanan, potensi hutan mangrove serta potensi alga. Pemanfaatan sumber daya perairan di Indonesia ini menunjang pembangunan kehidupan, baik sosial, ekonomi dan budaya (Baransano \& Mangimbulude, 2010).

Salah satu potensi sumber daya laut yang penting untuk dikaji adalah alga. Alga merupakan salah satu sumberdaya kelautan yang bernilai ekonomis yang di manfaatkan sebagai bahan industri farmasi, makanan, nutrasetika dan industri tekstil. Alga juga kaya akan senyawa ensensial untuk kehidupan berbagai mahkluk hidup, beberapa jenis alga memiliki kandungan bioaktif yang masuk ke dalam beberapa kelompok yaitu lemak, protein, polisakarida dan metabolit sekunder seperti pigmen, alkaloid, fenol dan lektin (Istifida \& Saptarini, 2018).

Alga Kappaphycus alvarezii adalah alga merah dari kelas Rhodophyceae, mempunyai dua warna yaitu hijau dan coklat serta merupakan alga penghasil karagenan (Dawes, 1998). Alga ini juga dimakan sebagai sayuran atau dibuat manisan oleh masyarakat.


Gambar 1. Alga K. alvarezii hijau (a) dan coklat (b) (Dokumentasi Pribadi, 2021).

Potensi keanekaraman laut Indonesia ini dapat mengalami penurunan yang disebabkan oleh pengaruh faktor pencemaran. Pencemaran dapat merusak tatanan lingkungan hidup, biasanya dapat berasal dari limbah-limbah yang sangat berbahaya dalam arti memiliki daya racun (toksisitas) yang tinggi. Maraknya pembuangan limbah ke sungai yang bermuara ke laut dari limbah industri, limbah cair pemukiman, limbah cair pertokoan, perkapalan dan pertanian menimbulkan dampak negatif bagi perairan serta menyebabkan kerusakan ekosistem bagi perairan sungai maupun laut (Santosa, 2013).

Dampak logam berat terhadap makro alga adalah menghambat pertumbuhan, karena logam berat dapat merusak kloroplas yang merupakan organ yang paling sensitif terhadap logam berat (Kepel $d k k$, 2018; Mantiri dkk, 2019), pada sedimen keberadaan logam berat arsen terdistribusi sebagai mineral.

\section{METODE PENELITIAN}

\section{Lokasi Penelitian}

Tempat penelitian dilakukan di Desa Buku Kecamatan Belang Kabupaten Minahasa Tenggara. Lokasi tersebut merupakan tempat budidaya alga yang dilakukan oleh masyarakat setempat, jarak lokasi budidaya alga dan pesisir berkisar 244 meter. Lokasi budidaya ini juga tidak jauh dari muara sungai dan persawahan serta berdekatan dengan tempat pembuatan kapal kayu milik masyarakat setempat.



Gambar 2. Peta Lokasi Penelitian 


\section{Budidaya Alga}

Bibit alga merah berwarna coklat dan hijau diambil dari masyarakat pembudidaya alga di Desa Buku Kecamatan Belang. Proses budidaya alga menggunakan metode apung (floating method)/longline yaitu posisi alga ditanam terapung di permukaan perairan mengikuti gerakan pasang surut. Bibit alga diambil dari 1 rumpun yang sama, kemudian dipisahkan menjadi ukuran kecil untuk dibudayakan lebih lanjut pada satu tali ris ukuran $5 \mathrm{~cm}$ dengan panjang $20 \mathrm{~m}$. Waktu untuk budidaya alga selama 6 (enam) minggu.

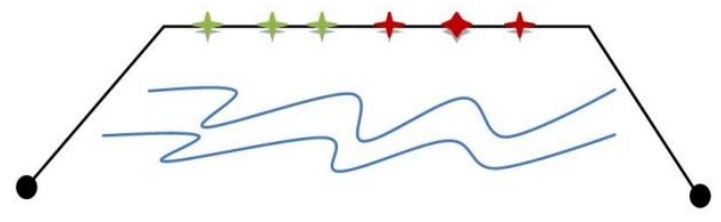

Gambar 3. Budidaya Alga

Pengambilan sampel sedimen dilakukan di lokasi tempat alga dibudiayakan. Proses pengambilan sedimen menggunakan pipa PVC berdiameter $12 \mathrm{~cm}$. Air laut tidak dianalisis karena telah dilaporkan dalam hasil penelitian Nasprianto dkk, (2019); Mantiri dkk (2019), bahwa air laut tidak terdeteksi adanya kandungan logam karena dipengaruhi oleh pola arus dan gelombang. Metcalf dan Edy (1978) menyebutkan karena kondisi hidrodinamika yang berbeda-beda menyebabkan tingkat pencemaran yang masuk ke dalam perairan berbeda-beda.

\section{Teknik Pengambilan Sampel Alga}

Pengambilan sampel alga $K$. alvarezii dilakukan pada minggu ke-1, minggu ke-3 dan minggu ke-5. Sampel diambil di satu tali ris tempat alga dibudidakan, sebanyak 100 g. Kemudian sampel alga dimasukkan ke dalam plastik sampel yang sudah ditandai dan diletakkan di dalam coolbox. Selanjutnya sampel disimpan dalam lemari pendingin pada suhu $-8^{\circ} \mathrm{C}$.
Pengambilan sampel untuk sedimen diambil di titik tempat alga dibudidayakan pada minggu ketiga. Pengambilan sedimen dilakukan dengan proses penyelaman dan menggunakan pipa PVC diameter $12 \mathrm{~cm}$, sebanyak 100 g. Setelah selesai pengambilan sampel secara keseluruhan, selanjutnya sampel dibawa di Laboratorium Balai Riset dan Standardisasi Industri Manado untuk dianalisis kandungan logam beratnya.

Dilakukan juga pengukuran kualitas air secara in-situ dengan beberapa parameter, antara lain salinitas diukur menggunakan refraktometer, temperatur diukur menggunakan termometer, untuk pengukuran salinitas dan temperatur dilakukan pengukuran setiap pengambilan sampel. Kecerahan air di ukur menggunakan secchi disk dengan meletakkan secchi disk di permukaan air hingga tenggelam sampai piringan secchi disk tidak terlihat lagi. Kecepatan arus di ukur dengan menggunakan metode Float tracking/Langrangian yaitu mengukur dengan menggunakan benda apung ke laut. Pengukuran menggunakan jarak dan perpindahannya benda apung. Benda apung yang digunakan adalah gabus.

\section{Prosedur Analisis Logam}

Analisis kandungan logam berat arsen pada alga dan sedimen dilakukan di Laboratorium Balai Riset dan Standardisasi Industri Manado, prosedur Analisis data menggunakan metode uji cemaran logam dalam makanan (SNI 01-1896-1998), yaitu:

Menggunakan proses destruksi basah sistem tertutup :

1 Sampel alga merah berwarna coklat dan hijau di potong menjadi kecil-kecil.

2 Selanjutnya sampel alga warna coklat dan hijau dan sedimen dimasukan dalam tabung vessel dan ditimbang menggunakan neraca antara $0.5-1 \mathrm{~g}$.

3 Setelah itu tambahkan asam nitrat sebanyak $10 \mathrm{ml}$ kemudian di diamkan beberapa menit sampai sampel tercampur. 
4 Selanjutnya pindahkan sampel ke dalam microwave digester pada suhu $210^{\circ} \mathrm{C}$, selama 5 jam hingga sampel berubah menjadi larutan jernih.

5 Siapkan labu ukuran $50 \mathrm{ml}$ kemudian saring sampel menggunakan kertas saring dan tambahkan aquades sampai pada tanda garis kemudian kocok.

Analisis sampel menggunakan Atomic Absorption Spectrophotometry (AAS) grafit furnace.

1 Larutan induk 1 ppm dilarutkan menjadi $1000 \mathrm{ppb}$.

2 Membuat larutan standart siapkan labu ukur $100 \mathrm{ml}$ kemudian masing-masing di masukkan 2,5 ppb, 5 ppb, 10 ppb, 15 pbb dan 20 pbb.

3 Kemudian dibaca menggunakan $A A S$ membentuk kurva kalibrasi.

\section{HASIL DAN PEMBAHASAN}

\section{Pengamatan Lokasi Penelitian}

Lokasi penelitian terletak di Desa Buku Kecamatan Belang Kabupaten Minahasa Tenggara. Lokasi budidaya alga ini berdekatan dengan daerah pemukiman masyarakat yang berjarak 244 meter dari pesisir pantai dan berdekatan juga tempat pembuatan kapal kayu milik masyarakat. Hal ini menurut Risna (2013), galangan kapal dapat berdampak negatif bagi kualitas perairan yang diakibatkan karena bahan penggunaan material pada pembuatan kapal yang memiliki kosentrasi logam yang tinggi seperti pengecetan lambung kapal dan bahan kimia $\mathrm{B}_{3}$ (Bahan Berbahaya beracun). Menurut Rompas (2010), zat kimia $B_{3}$ dapat berupa senyawa logam (anorganik) dan senyawa organik.

Lokasi pengambilan sampel juga berdekatan dengan muara sungai, dari segi visual muara sungai Perairan Belang nampak relatif bersih dibandingkan, lokasi penelitian Hosea dkk (2019) yaitu di muara sungai totok yang memiliki sedimentasi tinggi (kecerahan air $26 \mathrm{~cm}$ ), dikarenakan aktifitas pertambangan emas skala kecil.
Lokasi budidaya alga ini juga berjarak 441 meter dari area persawahan, para petani memanfatkan muara sungai sebagai tempat pembuangan akhir dari daerah persawahan.

\section{Analisis Parameter Kualitas Air Secara In-Situ}

Hasil pengukuran kualitas air dilakukan secara in-situ di lapangan adalah suhu/temperatur, salinitas, kecerahan dan kecepatan arus dapat dilihat pada Tabel 1 di bawah.

Tabel 1. Hasil Pengukuran Parameter Kualitas Air secara In-situ.

\begin{tabular}{|l|l|l|l|}
\hline No & $\begin{array}{l}\text { Parameter } \\
\text { Kualitas Air }\end{array}$ & $\begin{array}{l}\text { Perairan } \\
\text { Desa } \\
\text { Buku }\end{array}$ & $\begin{array}{c}\text { Standar } \\
\text { Baku } \\
\text { Mutu* }^{*}\end{array}$ \\
\hline 1. & Suhu & $29,6^{\circ} \mathrm{C}$ & Alami \\
\hline 1. & Salinitas & $34 \% \mathrm{o}$ & Alami \\
\hline 3. & Kecerahan & $3,28 \mathrm{~m}$ & $>5$ Meter \\
\hline 4. & $\begin{array}{l}\text { Kecepatan } \\
\text { arus }\end{array}$ & $\begin{array}{l}0,413 \\
\mathrm{~m} / \mathrm{s}\end{array}$ & - \\
\hline
\end{tabular}

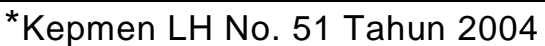

Menurut Wenno dkk (2014), alga memerlukan salinitas penuh untuk memperoleh pertumbuhan optimal, namun jika salinitas lebih rendah akan menimbulkan penyakit ice-ice, sebaliknya jika lebih tinggi menyebabkan layu permanen. Salinitas rata-rata di Perairan Desa Buku berkisar 34\%o, berdasarkan Kepmen LH No. 51 Tahun 2004 salinitas di Perairan Buku Belang alami dengan tingkat kecerahan 3,28 m, menurut Zainuddin dan Rusdani (2018), kecerahan berpengaruh pada pertumbuhan alga, rendahnya kecerahan menyebabkan matahari yang masuk kedalam perairan akan mempengaruhi proses fotosintesis.

Arus mempengaruhi alga, karena melalui pergerakan air nutrien-nutrien yang sangat dibutuhkan untuk perkembangan alga dapat tersuplai, terdistribusi dan kemudian diserap melalui thallus (Burdames dan Ngangi, 2014). Pengukuran kecepatan arus sebesar $0,413 \mathrm{~m} / \mathrm{s}$, arus pada pegukuran ini, arus tidak terlalu kuat sehingga tidak bepengaruh terjadinya penumpukan sampah di daerah budidaya 
alga. Lokasi budidaya alga berdekatan dengan pemukiman apabila terjadi arus kuat dan gelombang tinggi mengakibatkan sampah masyarakat berserakan di lokasi budidaya alga.

Analisis Kandungan Logam Berat Arsen (As) Pada Alga K.alvarezii Warna Coklat Dan Hijau Serta Sedimen.

Alga K.alvarezii yang merupakan sampel uji diambil dari lokasi budidaya alga di Perairan Desa Buku Kecamatan Belang Kabupaten Minahasa Tenggara. Hasil pengamatan logam berat arsen (As) yang terkandung pada alga K.alvarezii warna coklat dan hijau dan sedimen yang diperoleh seperti pada gambar 4 di bawah ini.



\section{Gambar 4. Grafik Konsentrasi Kandungan Logam Berat Arsen (As) Pada Alga Hijau dan Coklat.}

Terjadi tren kenaikan konsentrasi logam berat arsen pada alga yang dibudidaya di Perairan Belang dari minggu 1 sampai minggu ke 5 dimana alga hijau mengandung logam berat arsen lebih tinggi dari alga coklat yaitu sebesar 0.17-0.42 ppm untuk alga hijau dan 0.12-0.37 ppm untuk alga coklat. Proses naiknya kosentrasi logam berat arsen pada alga hijau dikarenakan alga hijau mengandung senyawa bioaktif lebih banyak dan kemungkinan alga hijau lebih resisten terhadap logam berat. Dari pengamatan ini logam berat arsen pada thallus tidak melebihi batas baku mutu Standart Nasional Indonesia (SNI) No. 7387 - 2009 untuk batas maksimum cemaran logam berat dalam pangan yaitu $1.0 \mathrm{ppm}$, namun sudah harus berhati-hati dalam mengelolah alga untuk dikomsumsi yang sudah terkontaminasi arsen karena dapat terakumulasi dalam rantai makanan. Penelitian Mantiri dkk (2019), alga memiliki kemampuan yang tinggi menyerap logam berat kerena gugus fungsi pada dinding sel sitoplasma alga yang mampu mengikat logam ion.

Menurut Rompas (2010), senyawa logam arsen (As) dapat berupa organik dan anorganik yang dimanfaatkan dalam dunia medis. Toksitas senyawa arsen umumnya terikat di alam dalam bentuk trivalent arsen $\left(\mathrm{AS}^{3+}\right)$ lebih beracun dari pada bentuk pentavalent $\left(\mathrm{AS}^{5+}\right)$ yang dimana trivalent arsen berperan menghambat kerja enzim. disisi lain arsenat tidak merupakan inhibitor terhadap enzim dan dapat masuk ke dalam fosfat. Sedangkan dalam peneltian ini senyawa arsen berbentuk pentavalent $\left(\mathrm{AS}^{5+}\right)$ sebab lebih banyak berikatan pada kalsium yang ada pada alga tersebut.

Pengamatan analisis kandungan logam arsen (As) pada sedimen di lokasi budidaya, mengandung konsentrasi logam sebesar 1,12 ppm lebih tinggi dari alga, namun tidak melebihi batas baku mutu Environmental Protection Agency (EPA) batas logam berat arsen pada sedimen maksimum $<10 \quad \mathrm{mg} / \mathrm{kg}$. Tingginya kandungan logam berat di sedimen diduga menjadi salah satu penyebab tingginya konsentrasi logam berat arsen pada alga yang dibudidaya di Perairan Desa Buku Kecamatan Belang. Menurut Kepel dkk (2018), logam berat memiliki berat molekul yang tinggi maka lebih mudah mengendap di sedimen. Susantoro dkk (2015) menyatakan bahwa logam berat memiliki sifat mengikat partikel lain dan bahan organik kemudian mengendap di dasar perairan dan bersatu dengan sedimen lainnya. Hal ini menyebabkan konsentrasi logam berat di dalam sedimen biasanya lebih tinggi dari pada perairan. Berdasarkan 
penelitian Hosea $d k k$, (2019); Kepel $d k k$, (2018); Siahaan $d k k$, (2017) telah terdeteksi beberapa jenis logam berat termasuk arsen di teluk totok. Jarak antara Teluk Totok dan Perairan Belang hanya sekitar $20 \mathrm{~km}$. Diduga banyak dipengaruhi oleh pengaruh aktifitas pertambangan di Ratatotok dengan kontribusi melalui sungai Totok, kehadiran logam arsen di sedimen di Desa Buku secara alamiah seperti dari beberapa sungai, dan abrasi pantai sekitar Desa Buku, sehingga keberadaan logam toksik ini dapat dikategorikan sebagai Non Point Source (Paulus dkk, 2020).

\section{KESIMPULAN}

Berdasarkan hasil penelitian yang dilakukan, maka dapat disimpulkan bahwa.

1 Kandungan logam berat arsen (As) pada alga Kapapphycus alvarezii warna coklat dan hijau telah terdeteksi namun tidak melebihi batas baku mutu SNI No. 7387 - 2009.

2 Konsentrasi logam berat arsen (As) mempunyai tren meningkat selama proses budidaya baik alga hijau maupun alga coklat.

3 Kadar As tertinggi pada minggu kelima (M-5) sebesar 0,41 ppm untuk alga hijau dan 0,37 ppm untuk alga coklat, menunjukan telah terjadi penyerapan logam berat arsen (As) pada thalus alga yang dibudidaya.

4 Analisis kandungan logam berat arsen (As) pada sedimen telah terdeteksi dengan konsentrasi sebesar 1,12 ppm. Masih lebih kecil dari standar baku mutu.

\section{DAFTAR PUSTAKA}

Baransano, H., \& Mangimbulude, J. (2010). Eksploitasi Konservasi Sumber Daya Hayati Laut dan Pesisi di Indonesia. Jurnal Biologi Papua, $3(1)$.

Hosea, F., Mantiri, D. M., Paulus, J., Rompas, R., Lumoindong, F., \& Mudeng, J. (2019). Analisis Logam Timbal (Pb) pada Kappaphycus alvarezii (Doty) Alga Merah yang di Budidaya di Teluk Totok Minahasa Tenggara, Sulawesi Utara. Jurnal Pesisir dan Laut Tropis, 7(3).

Istifida, D., \& Saptarini, N. M. (2018). Aktivitas Senyawa Bioaktif Alga Merah (Rhodophyta) sebagai Antimikroba. Jurnal Farmasi Universitas Padjadjaran, 16(1).

Kepel, R. C., Mantiri, D. M., Paransa, D., Paulus, J., Nasprianto, \& Wagey, B. (2018). Arsenic Content, Cell Structure, and Pigment of Ulva sp. from Totok Bay and Blongko Waters, North Sulawesi Indonesia. Jurnal AACL Bioflux, 11(3), 765771.

Mantiri, D. M., Kepel, R. C., Manoppo, H., Paulus, J., Paransa, D., \& Nasprianto. (2019). Metals in Seawater, Sediment and Padina australis, (Hauck 1887) Algae in the Waters of North Sulawesi. Jurnal AACL Bioflux, 11(3), 840-851.

Paulus, J. J., Mantiri, D. M., Kepel, R. C., Rumampuk, N. D., Rori , F., Pandey, E. V., et al. (2020). Study of Non Point Source Heavy Metal Cadmium Level In Mangrove lant Sediment At Likupang: Addressed To The Conservation of The Bunaken National Park. Jurnal IImiah Platax, 8(1).

Arisandi A., Farid A., Rokhmaniati S., 2013. Pertumbuhan Kappaphycus alvarezii yang terkontaminasi epifit di Perairan sumenep. Jurnal Kelautan. Vol 6, No 1 ISSN : 1907-9931

Burdames Y., dan Ngangi E., 2014. Kondisi lingkungan perairan budidaya rumput laut di Desa Arakan, Kabupaten Minahasa Selatan. Budidaya Perairan FPIK Unsrat Manado. Vol. 1 No.3.

Dawes, C.J. 1998. Marine Botany. Second Edition, John wiley and Sons, inc. University of South Florida. 480 hal.

Dawes J.C., Luisma A.O., TronoG.C., 1994. Laboratory and field growth studies of Eucheuma denticulatum and 
Kappaphycus alvarezii in the Philippines. Journal Kluwer Academic Publisher. Philippines. Hal 21-24.

Risna, 2013. Strategi pengelolaan lingkungan PT. Industri Kapal Indonesia Makassar dalam mengendalikan penceraman air dan udara. Universtas Hasanuddin Makasar.

Rompas R., 2010. Toksikologi Kelautan. PT. Walau Bengkulen. 338 halaman.

Santosa R., 2013. Dampak pencemaran lingkungan laut oleh perusahaan pertambangan terhadap nelayan tradisional. Lex Administratum, Vol. I/No. 1/Apr-Jun/2013.

Siahaan B., Mantiri D.M.H., Rimper J., 2017. Analisis logam timbal $(\mathrm{Pb})$ dan Kosentrasi Klorofil Pada Alga Padina australis Hauck Dari Perairan Teluk Totok dan Perairan Blongko, Provinsi Sulawesi Utara. Jurnal Pesisir dan Laut Tropis Vol.1 No 1

Susantoro T., Sunarjanto D., Andayani A., 2015. Distribusi logam berat pada sedimen di perairan muara dan laut Propinsi Jambi. Jurnal Kelautan Nasional, Vol 10 No 1 Hal 1-11.

Wenno., Syamsuddin., Latuihamallo., 2014. Beberapa parameter kimia yang mempengaruhi pertumbuhan rumput laut merah Kappaphycus alvarezii (Doty) di Perairan lebih dalam. Fakultas Perikanan Dan IImu Kelautan Universitas Pattimurah, Ambon.

Zainuddin F., Rusdani M., 2018. Performa romput laut Kappaphycus alvarezii dari Maumere dan Tambelang pada budidaya sistem longline. Jurnal of aquaculture Science Vol 3 (3): 116117. 